\title{
From the 7th Joint Italian-German Purine Club Meeting to European Purine Club Meetings
}

\author{
Felicita Pedata $^{1,2}$
}

Published online: 5 September 2017

(C) Springer Science+Business Media B.V. 2017

The 7th Joint Italian-German Purine Club Meeting"Advances in basic and translational purinergic research" has been held at the Sapienza University in Rome on July 20-22, 2017. The congress has been planned to provide an innovative and comprehensive overview of the latest research developments in the purine field, encouraging the contributions by young investigators. Special sessions were devoted to the roles of purines in central nervous system cell proliferation and maturation, in cancer and organ disease, in nervous transmission and pain, in structure and medicinal chemistry, in immunity and inflammation, and in the cardiovascular system. Attention has also been devoted to new putative purinergic therapeutics in different pathologies. Two plenary lectures were held and, according to tradition, we had the pleasure to welcome opening remarks by the "father of purines" Geoffrey Burnstock. The Italian Purine club was honored to award the prize "Giuliana Fassina" to Geoffrey Burnstock.

Participants were estimated in 140 scientists not only from Germany and Italy. We have welcomed the participation of eminent scientists in the field of purines from additional European countries, like Allison Gartland and Richard Evans from UK, Maria Teresa Miras-Portugal, Rafael Franco and Pablo Pelegrin from Spain, Ana Sebastiao from Portugal, Helle Praetorius and Jens Leipziger from Denmark,

Felicita Pedata

felicita.pedata@unifi.it

1 Department of Neuroscience, Psychology, Drug Research and Child Health (NEUROFARBA), University of Florence, Viale Pieraccini, 6, 50139 Florence, Italy

2 Division of Pharmacology and Toxicology, University of Florence, Viale Pieraccini, 6, 50139 Florence, Italy
Beata Sperlagh from Hungary, David Blum from France, Henning Ulrich from Brazil, and Tobias Engel from Ireland. The idea of the forthcoming establishment of European meetings had the approval of purine researchers who agreed that the purine field had grown up enough to feel the need to expand the German-Italian joint meetings to the other European countries. The kind and generous offering by Maria Teresa Miras-Portugal to organize the 1st European Congress on Purines in 2019 in Spain was welcomed with enthusiasm.

\section{The history of how the congresses of purines have grown up over time}

The history of purines as intercellular mediators initiates with the discovery by Drury and Szent-Gyorgyi in 1929 when adenosine and 5'-AMP were found to exert profound negative chronotropic effects and hypotensive actions [1]. Extracellular effects of purines were identified also in non-cardiovascular preparations in the years from 1932 to 1954 [2]. First indication that ATP might act as neurotransmitter in the peripheral nervous system was obtained by Holton and Holton in 1954 [3]. Few years later (1959), Pamela Holton could demonstrate, by a luminescence method of assay, that nerve electrical stimulation brought to a transient increase of ATP in the perfusion medium [4], while adenosine in the extracellular space might be a product of extracellular ATP or arise from neurons by itself [5]. The concept of purinergic co-transmission has been introduced by Burnstock in 1976 [6]. Two years later in 1978, the "International Conference on Physiological and Regulatory Functions of Adenosine and Adenine Nucleotides," held in Banff, Canada, served as an effective catalyst in enabling scientists with different points of view to exchange information and ideas on the role of purines. Since 1978, the amount of 
research on various aspects of adenosine metabolism, mechanism of action, transport and function in various tissues, in both normal and abnormal states, has increased exponentially. Four years later in 1982, an "International symposium on Adenosine" took place in Charlottesville, USA, organized by Robert M. Berne, Rafael Rubio, and Theodore W. Rall. Both meetings revealed an increased interest of scientists from numerous disciplines on biochemical, physiological, and pathophysiological aspects of adenosine as a proposed mediator of various specified regulatory functions, both at cellular and tissue level. In view of this newly emerging field, the "3rd International Symposium on Adenosine" was organized in Munich, Germany on June 1986. Members of the organizing committee were Hans P. Baer from Canada, Robert M. Berne from USA, Eckehart Gerlach, Georg. W. Kreutzberg, and Jürgen Schrader from Federal Republic of Germany (FRG). Fifty presentations by invited speakers and more than 120 posters defined the state of art of the topic at that time. In 1990, the 4th International Symposium on "Adenosine and Adenine Nucleotides" was held in Lake Yamanaka Japan, organized by Masahiro Mori and Yasuhiro Okada.

In 1992, Flaminio Cattabeni and Maria Pia Abbracchio organized the 1st international meeting in Italy, "Purines 1992", in Milan.

Since then, international meetings on Purines were held every 2 years in Europe and outside. In 1994, the "5th International Symposium on Adenosine and Adenine Nucleotides" was held in Philadelphia, PA, USA chaired by Luiz Belardinelli and Amir Pelleg. In 1996, "Purines 1996" was again organized in Milan by Flaminio Cattabeni and Maria Pia Abbracchio. In 1998, four hundred scientists from all over the world attended the 6th International Symposium on "Adenosine and Adenine Nucleotides" that took place in Ferrara chaired by Pier Andrea Borea and Pier Giovanni Baraldi [7]. "Purines 2000" chaired by Maria Teresa MirasPortugal and Jesùs Pintor followed in Madrid. The 7th International Symposium on "Adenosine and Adenine Nucleotides" was held in 2002 in Gold Coast Australia chaired by John P. Headrick. The 4th International Symposium on "Nucleosides and Nucleotides" followed in 2004 in Chapel Hill, NC, USA. The 8th International Symposium on "Adenosine and Adenine Nucleotides" in 2006 was again organized in Ferrara, Italy, chaired by Pier Andrea Borea, Francesco Di Virgilio, and Pier Giovanni Baraldi. Then, the international meeting "Purines 2008" was held in Copenhagen, Denmark organized by Ivana Novak, Davide Erlinge, and Jens Leipziger. "Purines 2010" in Tarragona, Spain was organized by Ana M. Sebastião, Artur Llobet, Carles Solsona, Enrique Castro, Esmerilda Delicado, Francisco Ciruela, Geoffrey Burnstock, Gloria Rosell, Jesús Pintor, Joaquim A. Ribeiro, Josefa Mallol, Lydia GiménezLlort, Mairena Martin, Marçal Pastor-Anglada, Mari CarmenMontesinos, Maria Pia Abbracchio, María Teresa
Miras-Portugal, Mireia Martín-Satué, Pablo Pelegrin, Paulo Correia-de-Sá, Pedro Rotllán, Pier Andrea Borea, Rafael Franco, Raquel Sen, Rodrigo Cunha, and Sergio Castillón. "Purines 2012" was in Fukuoka, Japan. "Purines 2014" in Bonn, Germany was organized by Anke Schiedel with Christa Müller and Herbert Zimmermann chairpersons. "Purines 2016" in Vancouver, Canada was organized by Joel Linden, Mark J. Smyth, Simon C. Robson, and Ken A. Jacobson. We welcome the next "Purines 2018" organized in Foz de Iguacu, Brazil by Henning Ulrich.

Several Purine Clubs were instituted in various parts of the world. In Europe, the first Italian Purine reunion was sponsored by Giuliana Fassina and Flaminio Cattabeni and held in Florence in 1985, organized by Giancarlo Pepeu and Felicita Pedata. The Italian Purine Club was formalized in 1990 with Lina Puglisi first President.

The German Purine Club was proposed by Herbert Zimmermann in 1995 and formalized in 2000 during the Madrid Purine Meeting with first President Herbert Zimmermann and vice President Peter Illes.

The common issue of purines by a large Italian and German scientific community led to the establishment of joint meetings that have been held alternatively in Italy and in Germany. The 1st one was held in 2005 in Chieti, Italy. The 2nd in 2007 Leipzig, Germany. The 3rd one in 2009 in Camerino, Italy. The 4th in 2011 in Bonn, Germany. The 5th in 2013 in Rimini, Italy. The 6th in 2015 was in Hamburg, Germany, and now the 7th in meeting has been held in 2017 Rome.

In 2009, the UK Purine Club was sponsored by Geoffrey Burnstock who was the first President and now Allison Gartland is the president. A 1st UK/Italian Purine Club Meeting was held in 2016 in Bristol, UK.

The interest on purines outside Europe brought to the Institution of the Japanize Purine Club by Kazuihide Inoue in 2003. In Brazil, a Purine Club was established in 2009, and the current president is Henning Ulrich. A North American Purine Club was established in 2009 by Ken Jacobson who stimulated common discussion among purine researchers over world by LinkedIn.

\section{Compliance with ethical standards}

Conflict of interest Author 1 declares that she has no conflict of interest.

Ethical approval This article does not contain any studies with human participants or animals performed by any of the authors.

\section{References}

1. Drury A, Szent-Gyorgyi A (1929) The physiological activity of adenine compounds with especial reference to their actions upon the mammalian heart. J Physiol 68:213-217 
2. Burnstock G, Fredholm BB, North RA, Verkhratsky A (2010) The birth and postnatal development of purinergic signalling. Acta Physiol (Oxf) 199:93-147

3. Holton FA, Holton P (1954) The capillary dilator substances in dry powders of spinal roots; a possible role of adenosine triphosphate in chemical transmission from nerve endings. J Physiol 126:124-140

4. Holton P (1959) The liberation of adenosine triphosphate on antidromic stimulation of sensory nerves. J Physiol 145:494-504
5. Latini S, Pedata F (2001) Adenosine in the central nervous system: release mechanisms and extracellular concentrations. J Neurochem 79:463-484

6. Burnstock G (1976) Do some nerve cells release more than one transmitter? Neuroscience 1:239-248

7. Borea PA, Baraldi PG (1998) Editorial sixth international symposium on adenosine and adenine nucleotides: new frontiers in the third millennium. Drug Dev Res 45:85 